In cooperation with the City of Houston

Continuous and Discrete Water-Quality Data Collected at Five Sites on Lake Houston near Houston, Texas, 2006-08

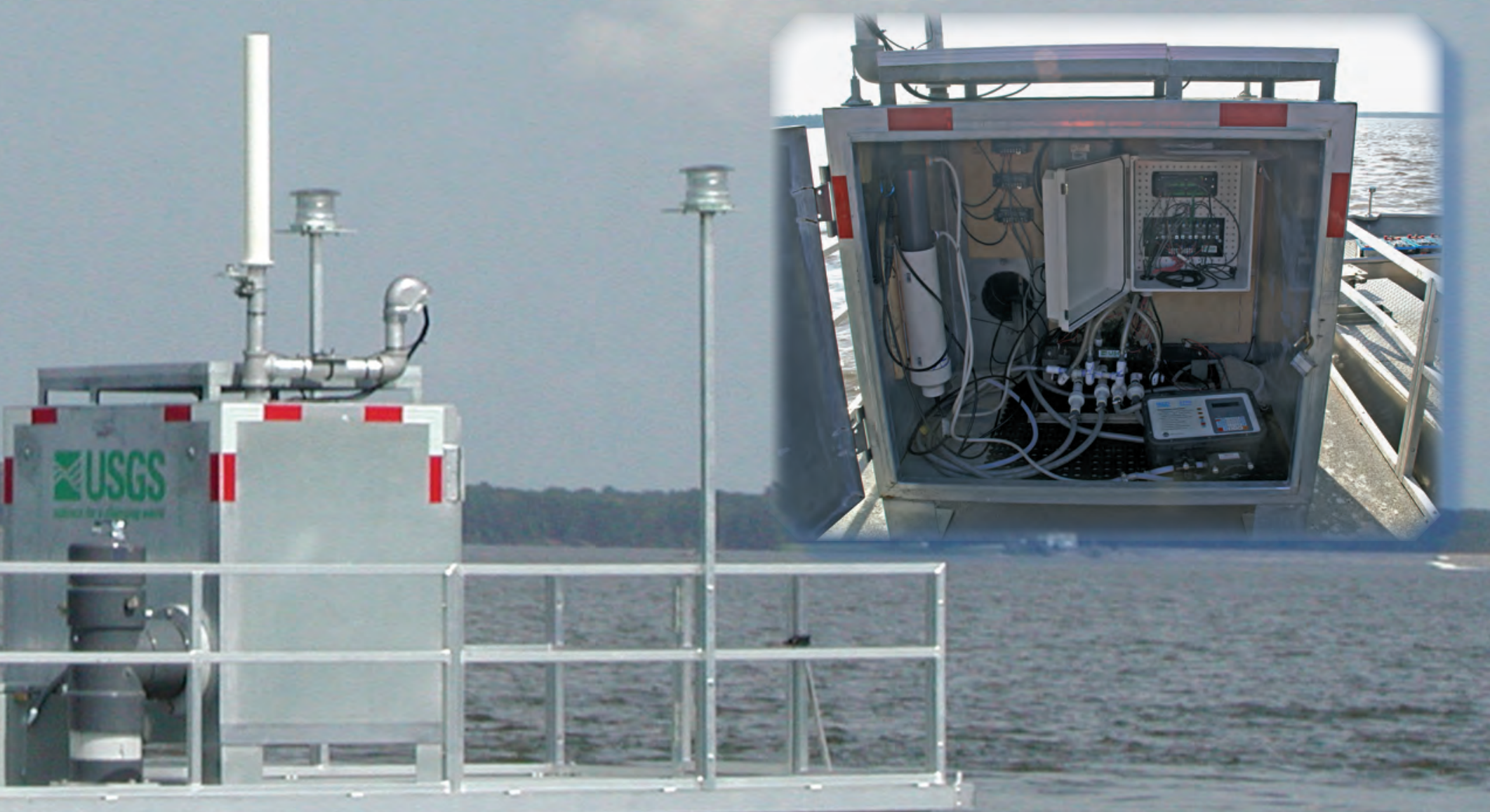

Data Series 485 
Cover: Anchored pontoon boat with data-collection system at monitoring station.

Front cover inset: Pump-and-switch system inside gage house.

\section{Back cover inset:}

Top, Gage house.

Bottom, Field measurements being made with sonde. 


\section{Continuous and Discrete Water-Quality Data Collected at Five Sites on Lake Houston near Houston, Texas, 2006-08}

By Amy M. Beussink and Michael R. Burnich

In cooperation with the City of Houston

Data Series 485 


\section{U.S. Department of the Interior \\ KEN SALAZAR, Secretary \\ U.S. Geological Survey \\ Marcia K. McNutt, Director}

U.S. Geological Survey, Reston, Virginia: 2009

This and other USGS information products are available at http://store.usgs.gov/
U.S. Geological Survey
Box 25286 , Denver Federal Center
Denver, CO 80225
To learn about the USGS and its information products visit http://www.usgs.gov/
1-888-ASK-USGS

Any use of trade, product, or firm names is for descriptive purposes only and does not imply endorsement by the U.S. Government.

Although this report is in the public domain, permission must be secured from the individual copyright owners to reproduce any copyrighted materials contained within this report.

Suggested citation:

Beussink, A.M., and Burnich, M.R., 2009, Continuous and discrete water-quality data collected at five sites on Lake Houston near Houston, Texas, 2006-08: U.S. Geological Survey Data Series 485, 18 p., appendixes online only. 


\section{Acknowledgments}

The authors thank the City of Houston Water Quality Laboratory for providing analytical services, and the City of Houston Public Works and Houston Police at Lake Houston for providing lake access, storage facilities, and security. The authors also acknowledge the following U.S. Geological Survey staff for their substantial contributions: Tim Oden for project management through June 2008 and for overall technical guidance throughout the study; Jennifer Graham for guidance in sampling design and limnology; Richard Kiesling and William Asquith for developing the initial "pump-and-switch" sampling system design for continuous, real-time water-quality monitoring; Ken VanZandt and Jason Ramage for gage house and platform design and construction; and Jeff East for technical direction and programming during the development and testing of the new data-collection and transmission system. Finally, because of unique challenges involving the application of new technology and the labor-intensive nature of the study, essentially everyone in the Gulf Coast Program Office of the U.S. Geological Survey Texas Water Science Center deserves recognition for contributing to the success of the study. 
Blank Page 


\section{Contents}

Abstract
Introduction
Purpose and Scope
Description of Study Area and Data-Collection Sites
$\quad$ Collection and Processing of Continuous Data
$\quad$ Qullection and Analysis of Discrete Data

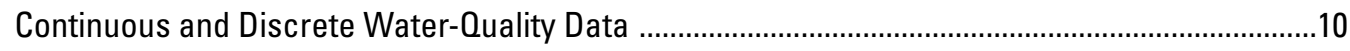

Summary

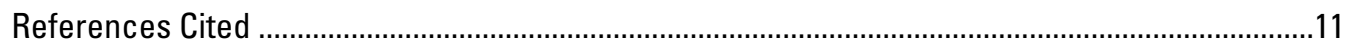

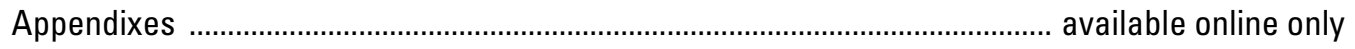

1-1. Routine measurements of physiochemical water-quality properties in samples from Lake Houston near Houston, Texas, 2006-08

1-2. Routine water-quality results for calcium and acid neutralizing capacity in samples from Lake Houston near Houston, Texas, 2006-08

1-3. Routine water-quality results for silica and manganese in samples from Lake Houston near Houston, Texas, 2006-08

1-4. Routine water-quality results for nutrients in samples from Lake Houston near Houston, Texas, 2006-08

1-5. Routine water-quality results for sediment and bacteria in samples from Lake Houston near Houston, Texas, 2006-08

1-6. Routine water-quality results for 2-methylisoborneol, geosmin, and total microcystin in samples from Lake Houston near Houston, Texas, 2006-08

1-7. Routine phytoplankton data in samples from Lake Houston near Houston, Texas, 2006-08

1-8. Biovolume summary by phytoplankton division of routine phytoplankton data in samples from Lake Houston near Houston, Texas, 2006-08

1-9. Cell summary by phytoplankton division of routine phytoplankton data in samples from Lake Houston near Houston, Texas, 2006-08

1-10. Phytoplankton taxa occurrence at each site for routine phytoplankton data in samples from Lake Houston near Houston, Texas, 2006-08

2-1. Synoptic water-quality results for major ions in samples from Lake Houston near Houston, Texas, 2006-08

2-2. Synoptic water-quality results for trace elements in samples from Lake Houston near Houston, Texas, 2006-08

2-3. Synoptic water-quality results for wastewater indicators in samples from Lake Houston near Houston, Texas, 2006-08

2-4. Synoptic water-quality results for pesticides in samples from Lake Houston near Houston, Texas, 2006-08

2-5. Synoptic water-quality results for volatile organic compounds in samples from Lake Houston near Houston, Texas, 2006-08

2-6. Synoptic water-quality results for carbons in samples from Lake Houston near Houston, Texas, 2006-08 
3-1. Continuous water-quality records for station 295724095092301, Lake Houston near Alcoa oil field near Houston, Texas, 2006-08

3-2. Continuous water-quality records for station 295826095082200 , Lake Houston south of Union Pacific Railroad Bridge near Houston, Texas, 2006-08

3-3. Continuous water-quality records for station 295554095093401, Lake Houston at mouth of Jack's Ditch near Houston, Texas, 2006-08

3-4. Continuous water-quality records for station 295510095084801, Lake Houston near Deussen Park near Houston, Texas, 2006-08

3-5. Continuous water-quality records for station 295435095082201, Lake at CWA (Coastal Water Authority) structure near Houston, Texas, 2006-08

\section{Figures}

1. Map showing location of monitoring stations on Lake Houston near Houston, Texas

2. Graph showing timeline of continuous water-quality monitoring station deployments and discrete, routine water-quality sampling for Lake Houston near Houston, Texas, 2006-08

3. Photograph showing U.S. Geological Survey continuous water-quality monitoring system at site B on Lake Houston, station 295554095093401, Lake Houston at mouth of Jack's Ditch near Houston, Texas

4. Hydrograph showing composite daily mean stream discharge to Lake Houston near Houston, Texas, and dates of discrete water-quality sampling for Lake Houston, 2006-08

\section{Tables}

1. Water-quality monitoring stations on Lake Houston near Houston, Texas, 2006-08 .......3

2. Routinely sampled discrete water-quality properties and constituents and corresponding analyzing entities for samples collected from Lake Houston near Houston, Texas, 2006-08

3. Synoptic water-quality properties and constituents and corresponding analyzing entities for samples collected from Lake Houston near Houston, Texas, 2006-08 ...........8

4. Summary of quality-control data and results for water-quality sampling, Lake Houston near Houston, Texas, 2006-08

5. Results of laboratory equipment blanks processed by the U.S. Geological Survey Texas Water Science Center, Gulf Coast Program Office (Houston) laboratory for samples collected from Lake Houston near Houston, Texas, 2006-08 


\section{Conversion Factors, Datums, and Water-Quality Units}

\section{Inch/Pound to SI}

\begin{tabular}{lcl}
\hline \multicolumn{1}{c}{ Multiply } & By & \multicolumn{1}{c}{ To obtain } \\
\hline & Length & \\
\hline foot $(\mathrm{ft})$ & 0.3048 & meter $(\mathrm{m})$ \\
mile $(\mathrm{mi})$ & 1.609 & kilometer $(\mathrm{km})$ \\
\hline & Area & \\
\hline square mile $\left(\mathrm{mi}^{2}\right)$ & 2.590 & square kilometer $\left(\mathrm{km}^{2}\right)$ \\
\hline & Volume & \\
\hline acre-foot (acre-ft) & 1,233 & cubic meter $\left(\mathrm{m}^{3}\right)$ \\
\hline
\end{tabular}

\section{SI to Inch/Pound}

\begin{tabular}{lcl}
\hline \multicolumn{1}{c}{ Multiply } & By & \multicolumn{1}{c}{ To obtain } \\
\hline & Length & \\
\hline centimeter $(\mathrm{cm})$ & 0.3937 & inch (in.) \\
meter $(\mathrm{m})$ & 3.281 & foot (ft) \\
\hline & Volume & \\
\hline liter $(\mathrm{L})$ & 33.82 & ounce, fluid (fl. oz) \\
\hline
\end{tabular}

Temperature in degrees Celsius $\left({ }^{\circ} \mathrm{C}\right)$ may be converted to degrees Fahrenheit $\left({ }^{\circ} \mathrm{F}\right)$ as follows:

$$
{ }^{\circ} \mathrm{F}=\left(1.8 x^{\circ} \mathrm{C}\right)+32
$$

\section{Datums}

Vertical coordinate information is referenced to the North American Vertical Datum of 1988 (NAVD 88).

Horizontal coordinate information is referenced to the North American Datum of 1983 (NAD 83).

\section{Water-Quality Units}

Specific conductance is given in microsiemens per centimeter at 25 degrees Celsius $(\mu \mathrm{S} / \mathrm{cm})$.

Concentrations of chemical constituents in water are given either in milligrams per liter (mg/L) or micrograms per liter $(\mu \mathrm{g} / \mathrm{L})$.

Bacteria is given in either most probable number per 100 milliliters (MPN/100 mL) or colonies per milliliter.

Turbidity is given in Formazine Nephelometric Units (FNU). 
Blank Page 


\title{
Continuous and Discrete Water-Quality Data Collected at Five Sites on Lake Houston near Houston, Texas, 2006-08
}

\author{
By Amy M. Beussink and Michael R. Burnich
}

\section{Abstract}

Lake Houston, a reservoir impounded in 1954 by the City of Houston, Texas, is a primary source of drinking water for Houston and surrounding areas. The U.S. Geological Survey, in cooperation with the City of Houston, developed a continuous water-quality monitoring network to track daily changes in water quality in the southwestern quadrant of Lake Houston beginning in 2006. Continuous water-quality data (the physiochemical properties water temperature, specific conductance, $\mathrm{pH}$, dissolved oxygen concentration, and turbidity) were collected from Lake Houston to characterize the in-lake processes that affect water quality. Continuous data were collected hourly from mobile, multi-depth monitoring stations developed and constructed by the U.S. Geological Survey. Multidepth monitoring stations were installed at five sites in three general locations in the southwestern quadrant of the lake. Discrete water-quality data (samples) were collected routinely (once or twice each month) at all sites to characterize the chemical and biological (phytoplankton and bacteria) response to changes in the continuous water-quality properties. Physiochemical properties (the five continuously monitored plus transparency) were measured in the field when samples were collected. In addition to the routine samples, discrete waterquality samples were collected synoptically (one or two times during the study period) at all sites to determine the presence and levels of selected constituents not analyzed in routine samples. Routine samples were measured or analyzed for acid neutralizing capacity; selected major ions and trace elements (calcium, silica, and manganese); nutrients (filtered and total ammonia nitrogen, filtered nitrate plus nitrite nitrogen, total nitrate nitrogen, filtered and total nitrite nitrogen, filtered and total orthophosphate phosphorus, total phosphorus, total nitrogen, total organic carbon); fecal indicator bacteria (total coliform and Escherichia coli); sediment (suspended-sediment concentration and loss-on-ignition); actinomycetes bacteria; taste-and-odor-causing compounds (2-methylisoborneol and geosmin); cyanobacterial toxins (total microcystins); and phytoplankton abundance, biovolume, and community composition (taxonomic identification to genus). Synoptic samples were analyzed for major ions, trace elements, wastewater indicators, pesticides, volatile organic compounds, and carbon. The analytical data are presented in tables by type (continuous, discrete routine, discrete synoptic) and listed by station number. Continuously monitored properties (except $\mathrm{pH})$ also are displayed graphically.

\section{Introduction}

Houston, Tex., is the fourth largest city in the United States; the population of the greater Houston area was about 5.6 million in 2008 (Texas State Data Center, 2008). Lake Houston is an important surface-water source for Houston and surrounding areas. The dam impounding Lake Houston was constructed in 1954 by the City of Houston $(\mathrm{COH})$ to provide public water supply and irrigation water; the reservoir has a current capacity of about 130,000 acre-feet (Texas Water Development Board, 2004). Lake Houston is in northern Harris and southeastern Montgomery Counties about 25 miles east-northeast of downtown Houston (fig. 1).

The U.S. Geological Survey (USGS), in cooperation with the City of Houston, implemented a water-quality monitoring network in 2006 to collect continuous (hourly) data for physiochemical properties (water temperature, specific conductance, $\mathrm{pH}$, dissolved oxygen concentration, and turbidity) in Lake Houston. Mobile, multi-depth continuous monitoring stations were installed at five sites in the southwestern quadrant of Lake Houston (fig. 1; table 1). Discrete water-quality samples were collected routinely (once or twice per month) (fig. 2) at the sites where physiochemical properties were continuously monitored. Physiochemical properties (the five continuously monitored plus transparency) were measured in the field when water-quality samples were collected. Routine waterquality samples were measured or analyzed for acid neutralizing capacity (ANC), selected major ions and trace elements, nutrients, fecal indicator bacteria, suspended-sediment concentration and loss-on-ignition, actinomycetes bacteria; taste-and-odor-causing compounds, cyanobacterial toxins, and phytoplankton abundance, biovolume and community composition. Discrete water-quality samples were collected synoptically at all sites one or two times during the study period to determine the presence and levels of selected constituents not analyzed in routine samples-major ions, trace elements, wastewater indicators, pesticides, volatile organic compounds (VOCs), and carbon. 


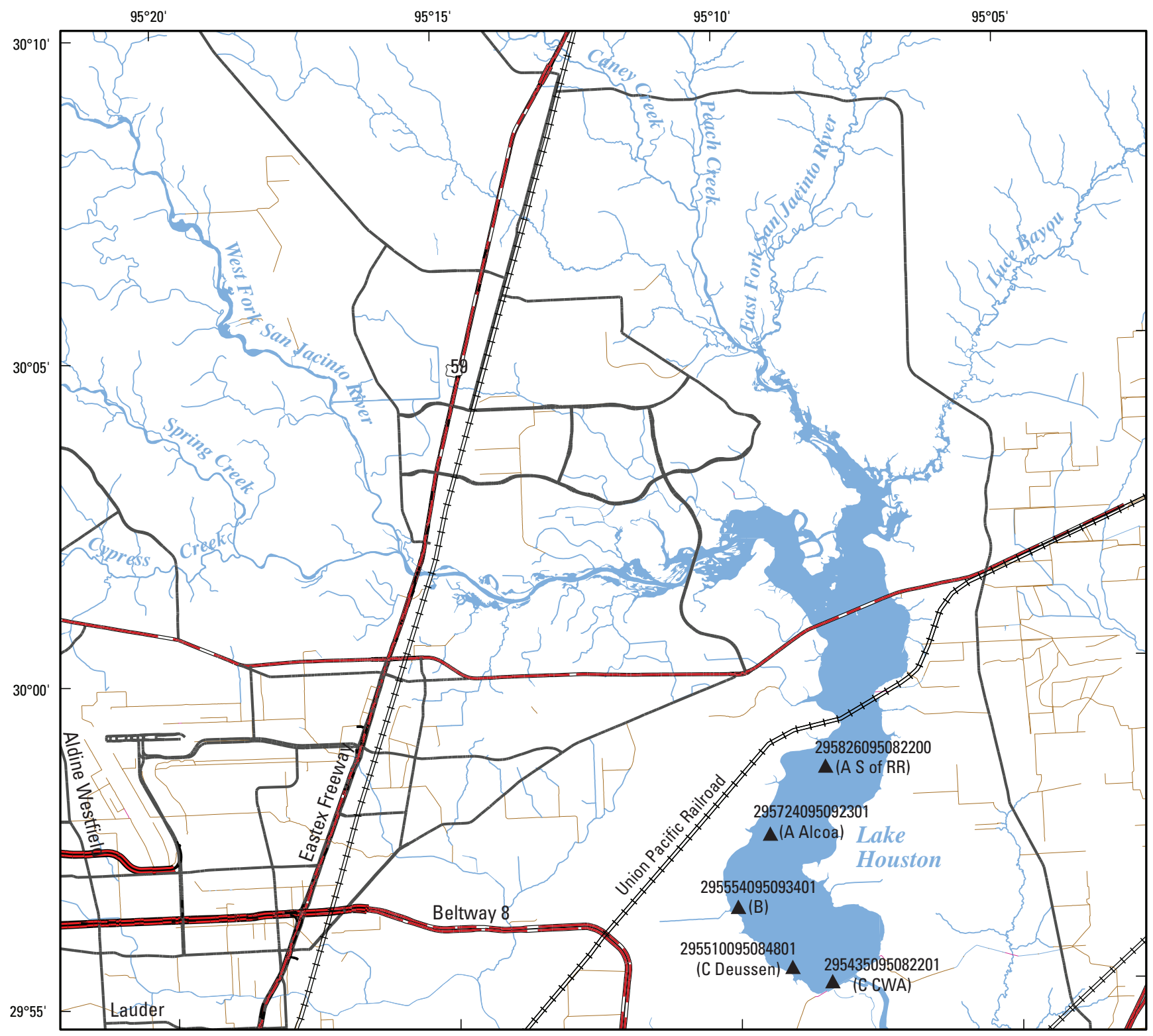

Base from:

U.S. Geological Survey digital data-Rivers, streams, and lakes Texas Natural Resources Information System-Roads and cities State Plane Coordinate System, Zone 4

North American Datum of 1983

EXPLANATION

295554095093401

(B)
U.S. G eological Survey water-quality monitoring station-Station number and site short name (table 1)

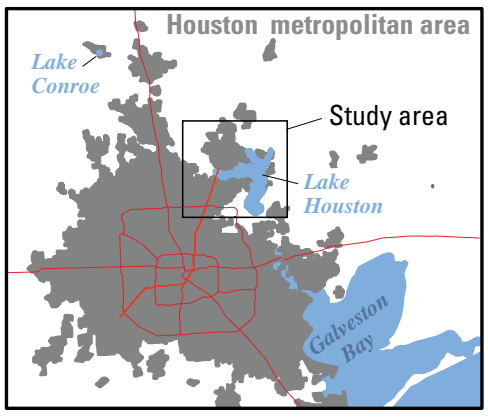

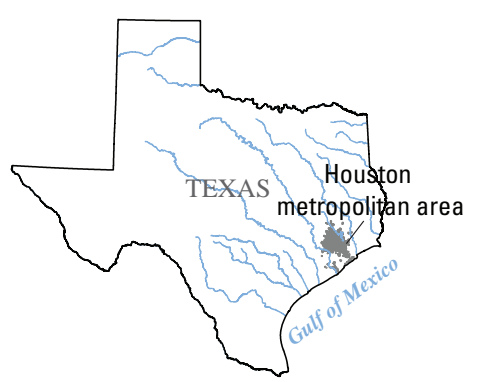

LOCATION MAP

Figure 1. Location of monitoring stations on Lake Houston near Houston, Texas. 


\begin{tabular}{|c|c|c|c|c|c|c|c|c|c|c|c|c|c|c|c|c|c|c|c|c|c|c|c|c|c|c|c|c|}
\hline \multirow{2}{*}{$\begin{array}{l}\text { Site short name } \\
\text { (fig. 1; table 1) }\end{array}$} & \multirow[t]{2}{*}{ Station number } & \multicolumn{10}{|c|}{2006} & \multicolumn{9}{|c|}{2007} & \multicolumn{8}{|c|}{2008} \\
\hline & & $J$ & $\mathrm{~F}$ & $\mathrm{M}$ & $\mathrm{A} \mid \mathrm{I}$ & M & \begin{tabular}{l|l}
$\mathrm{J}$ & $\mathrm{J}$ \\
\end{tabular} & $\mathrm{A}$ & \begin{tabular}{l|l}
$S$ & 0
\end{tabular} & $\mathrm{~N}$ & $\mathrm{D}$ & $\mathrm{J}$ & $\mathrm{F}$ & $\mathrm{M} \mid \mathrm{A}$ & \begin{tabular}{l|l}
$A$ & $M$ \\
\end{tabular} & $\mathrm{~J}$ & \begin{tabular}{l|l}
$\mathrm{J}$ & $\mathrm{A}$
\end{tabular} & \begin{tabular}{l|l|}
$A$ & $S$ \\
\end{tabular} & \begin{tabular}{l|l}
0 & 1 \\
\end{tabular} & $\mathrm{~N}$ & \begin{tabular}{l|l|}
$\mathrm{D}$ & $\mathrm{J}$ \\
\end{tabular} & $\mathrm{F}$ & $\mathrm{M} / \mathrm{A}$ & \begin{tabular}{l|l|}
$A$ & $M$ \\
\end{tabular} & $\mathrm{~J}$ & $\mathrm{~J}$ & $\mathrm{~A}$ & S \\
\hline A Alcoa & 295724095092301 & & & & & 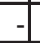 & & -- & -- & & & & -- & & & -- & $-\ldots$ &.-- & & - & & -10 & & & - & 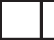 & & \\
\hline $\mathrm{B}$ & 295554095093401 & & & & - & - & - & -- & -- & & - & & -- & & - & -- &.-- & --- & & -- & -- & --- & - & --- & & -- & & - \\
\hline C Deussen & 295510095084801 & & & & - & - & - & - & -1 & & - & - & -- & & - & -- &.-- & -1 & & 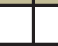 & \begin{tabular}{l|l} 
& \\
\end{tabular} & 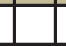 & 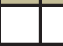 & 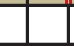 & 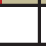 & 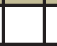 & & \\
\hline
\end{tabular}

Figure 2. Timeline of continuous water-quality monitoring station deployments and discrete, routine water-quality sampling for Lake Houston near Houston, Texas, 2006-08.

\section{Purpose and Scope}

The purpose of this report is to present the continuously monitored water-quality data and the water-quality data from discrete samples collected by the USGS in Lake Houston from April 2006 through September 2008. Methods used to collect and analyze the continuous and discrete water-quality data are described. This report complements previous USGS reports on the conditions and trends of water quality in Lake Houston since 1983 (Liscum and others, 1999; Liscum and East, 2000; Sneck-Fahrer and others, 2005; Oden and Graham, 2008; U.S. Geological Survey, 2009).

\section{Description of Study Area and Data-Collection Sites}

Lake Houston is at the outlet of the 2,835-square-mile San Jacinto River watershed in southeastern Texas (fig. 1). The watershed for Lake Houston includes two main tributaries, the East Fork San Jacinto River and the West Fork San Jacinto River. The East Fork San Jacinto River drains a predominantly rural, undeveloped woodland landscape with mainly agriculture and forestry land uses (Sneck-Fahrer and others, 2005). Tributaries in the East Fork San Jacinto River watershed include Peach Creek, Caney Creek and Luce Bayou. The West

Table 1. Water-quality monitoring stations on Lake Houston near Houston, Texas, 2006-08.

[USGS, U.S. Geological Survey; CWA, Coastal Water Authority]

\begin{tabular}{|c|c|c|c|c|}
\hline $\begin{array}{l}\text { Site short } \\
\text { name } \\
\text { (fig. 1) }\end{array}$ & $\begin{array}{l}\text { USGS station } \\
\text { number }\end{array}$ & Station name & $\begin{array}{l}\text { Date of discrete } \\
\text { sampling }\end{array}$ & $\begin{array}{l}\text { Period of continuous monitoring } \\
\text { (monitoring depths below } \\
\text { water surface, in feet) }\end{array}$ \\
\hline A Alcoa & 295724095092301 & $\begin{array}{l}\text { Lake Houston near Alcoa oil field near } \\
\text { Houston, Texas }\end{array}$ & $\begin{array}{l}\text { April 2006-January } \\
\quad 2008\end{array}$ & $\begin{array}{l}\text { October } 2006 \text {-February } 2008 \\
\left(1,3.5,6,{ }^{1} 6\right)\end{array}$ \\
\hline A $S$ of RR & 295826095082200 & $\begin{array}{l}\text { Lake Houston south of Union Pacific } \\
\text { Railroad Bridge near Houston, } \\
\text { Texas }\end{array}$ & $\begin{array}{l}\text { March 2008-September } \\
\quad 2008\end{array}$ & $\begin{array}{l}\text { April 2008-September } 2008 \\
(1,6,12,16)\end{array}$ \\
\hline B & 295554095093401 & $\begin{array}{l}\text { Lake Houston at mouth of Jack's Ditch } \\
\text { near Houston, Texas }\end{array}$ & $\begin{array}{l}\text { April 2006-September } \\
2008\end{array}$ & $\begin{array}{l}\text { October 2006-September } 2008 \\
(1,6,12,16)\end{array}$ \\
\hline C Deussen & 295510095084801 & $\begin{array}{l}\text { Lake Houston near Deussen Park near } \\
\text { Houston, Texas }\end{array}$ & $\begin{array}{l}\text { April 2006-September } \\
2007\end{array}$ & $\begin{array}{l}\text { January 2007-September } 2007 \\
(1,3,5,7)\end{array}$ \\
\hline C CWA & 295435095082201 & $\begin{array}{l}\text { Lake Houston at CWA structure near } \\
\text { Houston, Texas }\end{array}$ & $\begin{array}{l}\text { September 2007-July } \\
2008\end{array}$ & $\begin{array}{l}\text { September 2007-July } 2008 \\
(1,6,12,16)\end{array}$ \\
\hline
\end{tabular}


Continuous and Discrete Water-Quality Data Collected at Five Sites on Lake Houston near Houston, Texas, 2006-08

Fork San Jacinto River drains a primarily urban watershed with residential and commercial development, major transportation corridors, and fluvial gravel and sand mining operations. Tributaries to the West Fork San Jacinto River include Cypress Creek and Spring Creek. Flow in the main stem of the West Fork San Jacinto River is discharged from Lake Conroe, a reservoir about 32 linear miles (40 stream miles) upstream from Lake Houston, near the headwaters of the West Fork San Jacinto River. Downstream from the outlet of Lake Houston, the San Jacinto River drains into a coastal bayou system.

The mean depth of Lake Houston is about 12 feet and the maximum depth is about 50 feet (Liscum and East, 2000). Data were collected from five sites in three general locations (location incorporated in site short name as $\mathrm{A}, \mathrm{B}$, and C) in the southwestern quadrant of the lake (fig. 1; table 1): site A Alcoa (Lake Houston near Alcoa oil field near Houston, Tex., station 295724095092301); site A S of RR (Lake Houston south of Union Pacific Railroad Bridge near Houston, Tex., station 295826095082200); site B (Lake Houston at mouth of Jack's Ditch near Houston, Tex., station 295554095093401); site C Deussen (Lake Houston near Deussen Park near Houston, Tex., station 295510095084801); and site C CWA (Lake Houston at Coastal Water Authority (CWA) structure near Houston, Tex., station 295435095082201). The original site A station (A Alcoa) and the original site C station (C Deussen) were in shallower water than the site B station; those two stations were relocated to deeper parts of the lake partway through the study period so that the maximum water depth at all sites was similar (thus the reason for two "A" sites and two "C" sites). Site A Alcoa, originally near Alcoa oil field, was discontinued at the end of February 2008 and replaced in April 2008 by Site A S of RR, south of the Union Pacific Railroad bridge (fig. 2; table 1). Site C Deussen, near Deussen Park, was discontinued and replaced in September 2007 by site C CWA, closer to the CWA structure. Site C CWA was discontinued in July 2008.

\section{Methods}

Physiochemical properties were monitored hourly at four depths in the water column at five sites in Lake Houston. Discrete water-quality samples were collected routinely (once or twice most months from April 2006 through September 2008) at the sites where physiochemical properties were continuously monitored. Routine water-quality samples were analyzed for selected properties and constituents. Discrete water-quality samples were collected synoptically (one or two times during the study period) at the five sites and analyzed for constituents not measured in the routine water-quality samples. All data collection and analysis followed documented methods and quality-control (QC) procedures. Continuous and discrete-sample water-quality data were collected using USGS methods documented in the "National Field Manual for the Collection of Water-Quality Data" (U.S. Geological Survey, variously dated).

\section{Collection and Processing of Continuous Data}

Continuous water-quality data were collected from Lake Houston to characterize the in-lake processes that affect water quality. Continuous data were collected hourly from mobile, multi-depth monitoring stations developed and constructed by the USGS (fig. 3). Each monitoring station included a datacollection system (an anchored pontoon boat) with a gage house, a portable multi-probe sonde, solar panels, 12-volt batteries, a data recorder and transmitter, and an omnidirectional antenna. The multi-probe sondes were calibrated to standards certified by the USGS National Water Quality Laboratory (NWQL) in Denver, Colo. The first version of the data-collection system consisted of a "pump-and-switch" system (fig. 2) whereby lake water was pumped from different lake depths through tubing of various lengths into a flow-through chamber in the gage house. In the flow-through chamber, physiochemical water-quality properties were measured by the portable multi-probe sonde as lake water pumped up from the specified depth flowed through the chamber. Frequent algal biofouling of the pump-and-switch tubing led to development of a new version of multi-depth monitoring. Between September 2007 and June 2008, a new version of the data-collection system using an automatic profiling system was installed at each site to replace the original "pump-andswitch" system (fig. 2). In the automatic profiling system, the portable multi-probe sonde was lowered by an automated reel system to specified depths in the water column. For both versions of the data-collection system, physiochemical water-quality properties were measured every 15 minutes and transmitted hourly for four depths, cycling from the shallowest to the deepest depth, for the deeper sites (table 1). For example, at site B, measurements of physiochemical waterquality properties from 1 foot below the water surface were made at 15 minutes past the hour, measurements from 6 feet below the water surface were made at 30 minutes past the hour, measurements from 12 feet below the water surface were made at 45 minutes past the hour, and measurements from 16 feet below the water surface were made at the top of the hour. Measurements for all depths from a given hour were stored in the system and then transmitted hourly through the National Oceanic and Atmospheric Administration (NOAA) Geostationary Operational Environmental Satellite (GOES) network. The data then were transferred into the USGS National Water Information System (NWIS) database and displayed on the Web (U.S. Geological Survey, 2009).

The continuous water-quality data were processed following USGS methods and guidelines from Wagner and others (2006). The record-computation process included an initial data evaluation, application of corrections and shifts, a final data evaluation, record checking, and record review. The application of cross-section corrections was not done as described in Wagner and others (2006) because the samples were collected from a lake, not a stream. QC limits for correcting data, referred to as "maximum allowable limits," were established for each physiochemical property. If the recorded values 


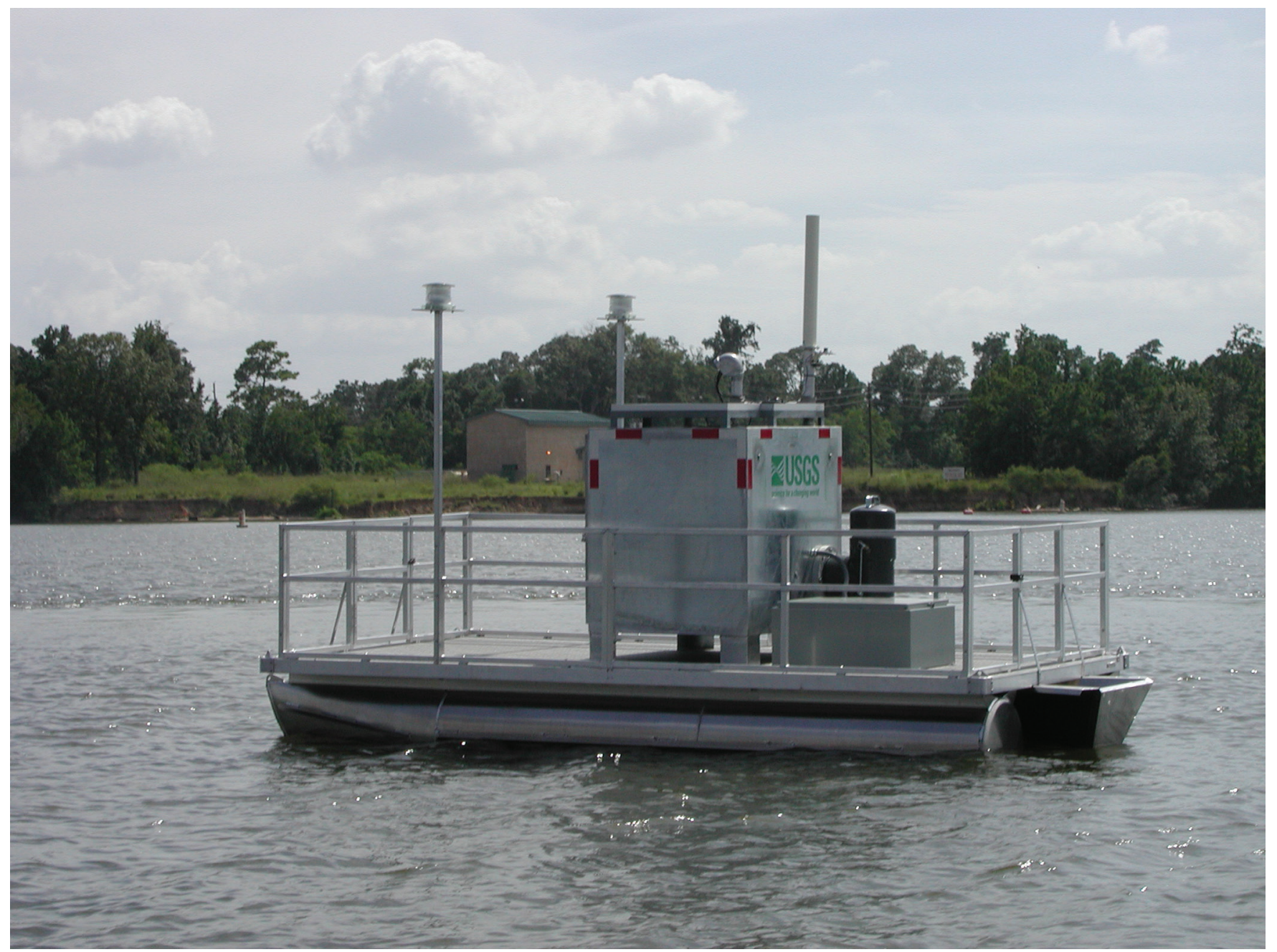

Figure 3. U.S. Geological Survey continuous water-quality monitoring system at site B on Lake Houston, station 295554095093401, Lake Houston at mouth of Jack's Ditch near Houston, Texas (photograph by T.D. Oden, August 14, 2006).

differed from the corrected values by more than the maximum allowable limits, the corrected data were not reported or stored in the database. Corrected data that exceeded the maximum allowable limits for each physiochemical property as defined by Wagner and others (2006) were removed from the record, except for turbidity. For turbidity data, Wagner and others (2006) recommends a maximum allowable limit of \pm 3.0 Nephelometric Turbidity Units (NTU) or \pm 30 percent, whichever is greater. Continuously recorded turbidity data that differ from field-measured turbidity data by more than 30 percent generally are not published or stored in the database. In 12 instances, the maximum allowable limit for turbidity data variability was modified to \pm 50 percent. The highly turbid nature of water in Lake Houston inhibits algal growth by limiting light penetration into the water column (Lee and Rast, 1997). As water was pumped through the tubing of the pumpand-switch system, increased ambient temperature as water from depth was brought closer to the surface resulted in algal growth and biofouling on the inside surfaces of the tubing and flow-through chamber. Increased biofouling in the tubing and flow-through chamber resulted in higher-than-actual turbidity values, occasionally exceeding the \pm 30 percent limit. However, field measurements during site visits demonstrated that shifts could be applied to the continuous data beyond the maximum allowable limit to retain valid turbidity values under these conditions. The 12 instances for which the maximum allowable limits for variability were modified to \pm 50 percent are as follows: at site A Alcoa on November 16, 2006, July 3, 2007, September 19, 2007, December 31, 2007, January 30, 2008, and February 7, 2008; at site A S of RR on May 13, 2008; at site B on October 11, 2007, and April 3, 2008; and at site C Deussen on February 22, 2007, April 25, 2007, and August 2, 2007. The data for turbidity at site C CWA was always within the \pm 30 percent limit. All instances involved turbidity values less than 60 NTU, and most involved values less than 30 NTU. When the turbidity data variability 
exceeded \pm 30 percent but was less than the \pm 50 -percent limit, the antecedent and subsequent data patterns were carefully reviewed. If the data were considered reasonable they were kept as part of the record. This modification of the maximum allowable limit for turbidity data for certain periods made it possible to retain certain turbidity values as indicators of possible changes in the condition of the lake related to runoff events or related to stratification. In these cases, because the turbidity data beyond the \pm 30 -percent limit followed antecedent and subsequent data patterns, the data were considered reasonable and kept as part of the record. As noted by Wagner and others (2006), professional judgment by the hydrographer is needed in record processing.

\section{Collection and Analysis of Discrete Data}

Discrete water-quality data (samples) were collected routinely at all sites to characterize the chemical and biological (phytoplankton and bacteria) response to changes in the continuous water-quality properties. Routine samples were collected monthly in April, May, June, and July 2006, prior to installation of the continuous water-quality monitoring stations. Beginning in August 2006, water-quality samples from each monitoring site were collected monthly, with a bi-weekly sampling schedule in the summer (fig. 2). The physiochemical properties water temperature, specific conductance, $\mathrm{pH}$, dissolved oxygen concentration, turbidity, and transparency were measured in the field when samples were collected.

Routine water-quality samples were collected over a range of stream discharges into Lake Houston. Sample collection dates and composite daily discharge to Lake Houston are shown (fig. 4). Composite daily discharge was computed from measured discharge at USGS streamflow-gaging stations on tributaries to Lake Houston: 08069000 Cypress Creek near Westfield, Tex., 08068500 Spring Creek near Spring, Tex., 08068090 West Fork San Jacinto River above Lake Houston near Porter, Tex., 08070500 Caney Creek near Splendora, Tex., 08071000 Peach Creek near Splendora, Tex., 08070200

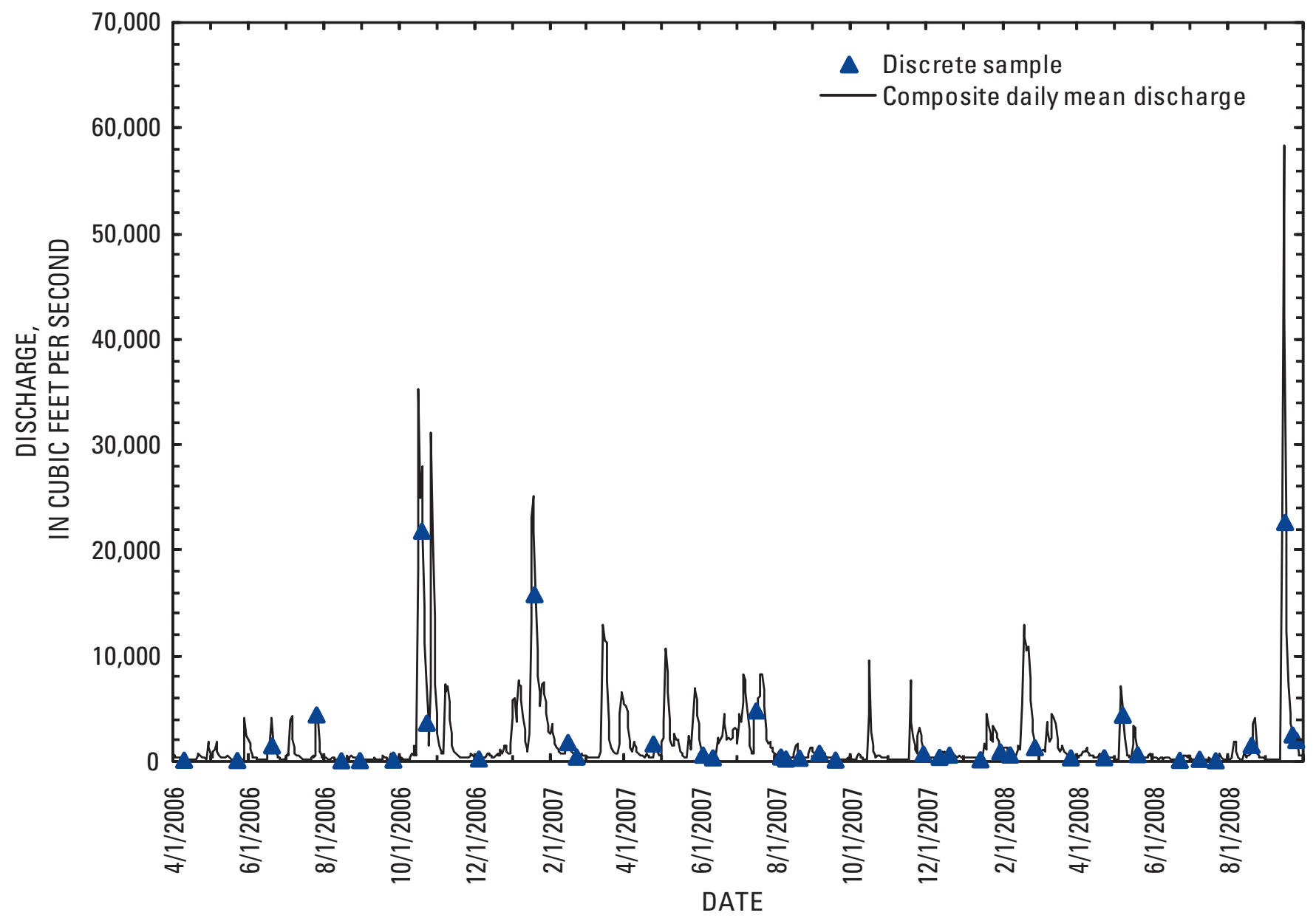

Figure 4. Hydrograph showing composite daily mean stream discharge to Lake Houston near Houston, Texas, and dates of discrete water-quality sampling for Lake Houston, 2006-08. 
East Fork San Jacinto River near New Caney, Tex., and 08071280 Luce Bayou above Lake Houston near Huffman, Tex.

At each site, routine samples were collected at about 1 foot below the water surface, at the midpoint depth of the water column, and at about 1 foot above the bottom of the lake. Water was pumped from these specified depths in the water column through Teflon-lined tubing using a peristaltic pump. One end of the tubing was attached alongside a portable multi-probe sonde and lowered into the water column. Water was collected in sample bottles from the other end of the tubing and measurements of physiochemical properties were recorded for each sample depth. In between the collection of samples at a site, water in the tubing was purged from the line using water from the next depth. A clean set of tubing was used at each site.

Routine samples collected on September 16, 2008, three days after Hurricane Ike made landfall in the Houston area, were collected differently than other discrete samples. Instead of a peristaltic pump and Teflon-lined tubing, a Kemmerer sampler was used to collect depth-integrated samples at site A $\mathrm{S}$ of RR and site B. At each site, 1 liter of water was collected at the top, middle, and bottom depths and composited into a 3 -liter Teflon bottle. Samples were later processed from the integrated sample.
In addition to the routine samples, synoptic samples were collected at all sites one or two times during the study period to determine the presence and levels of selected constituents not analyzed in routine samples. Synoptic samples were collected in the same manner as the routine samples. Routinely collected samples (table 2) were measured or analyzed for ANC; selected major ions and trace elements (calcium, silica, and manganese); nutrients (filtered and total ammonia nitrogen, filtered nitrate plus nitrite nitrogen, total nitrate nitrogen, filtered and total nitrite nitrogen, filtered and total orthophosphate phosphorus, total phosphorus, total nitrogen, total organic carbon); fecal indicator bacteria (total coliform and Escherichia coli [E. coli]); suspended-sediment concentration and loss-on-ignition; actinomycetes bacteria; taste-and-odorcausing compounds (2-methylisoborneol [MIB] and geosmin); cyanobacterial toxins (total microcystins); and phytoplankton abundance, biovolume, and community composition (taxonomic identification to genus).

Routine samples were sent to numerous laboratories (table 2) for analysis using various methods. Calcium was analyzed by the NWQL following methods described in Garbarino and Struzeski (1998). ANC was analyzed by USGS personnel at the Texas Water Science Center (WSC) laboratory in The Woodlands by inflection-point titration (U.S. Geological Survey, variously dated) and at the NWQL following

Table 2. Routinely sampled discrete water-quality properties and constituents and corresponding analyzing entities for samples collected from Lake Houston near Houston, Texas, 2006-08.

[GCPO, U.S. Geological Survey (USGS) Texas Water Science Center (WSC) Gulf Coast Program Office, The Woodlands, Texas; NWQL, USGS National Water Quality Laboratory, Denver, Colorado; COH, City of Houston Department of Public Works Water Quality Laboratory, Houston, Texas; LASD, USGS Louisiana WSC Sediment Laboratory, Baton Rouge, Louisiana; KYSD, USGS Kentucky WSC Sediment Laboratory, Louisville, Kentucky; OML, USGS Ohio WSC Microbiology Laboratory, Columbus, Ohio; OGRL, USGS Kansas WSC Organic Geochemistry Research Laboratory, Lawrence, Kansas; PhycoTech, PhycoTech Inc., St. Joseph, Michigan]

\begin{tabular}{|c|c|c|c|c|c|c|c|c|}
\hline Constituent & GCPO & NWOL & $\mathrm{COH}$ & LASD & KYSD & OML & OGRL & PhycoTech \\
\hline $\begin{array}{l}\text { Physiochemical properties (sampling depth, transparency, } \\
\text { barometric pressure, dissolved oxygen concentration, } \mathrm{pH} \text {, } \\
\text { specific conductance, air temperature, water temperature) }\end{array}$ & $\mathrm{X}$ & & & & & & & \\
\hline Acid neutralizing capacity (ANC) & $\mathrm{X}$ & $X$ & & & & & & \\
\hline $\begin{array}{l}\text { Selected major ions and trace elements (silica, calcium, } \\
\text { manganese) }\end{array}$ & & $X$ & $\mathrm{X}$ & & & & & \\
\hline $\begin{array}{l}\text { Nutrients (ammonia plus organic nitrogen, ammonia, nitrate } \\
\text { plus nitrite, nitrate, nitrite, total nitrogen, orthophosphate, } \\
\text { phosphorus) }\end{array}$ & & $\mathrm{X}$ & $\mathrm{X}$ & & & & & \\
\hline Fecal indicator bacteria (total coliform, Escherichia coli) & $\mathrm{X}$ & & & & & & & \\
\hline Suspended sediment & & & & $\mathrm{X}$ & $\mathrm{X}$ & & & \\
\hline Sediment loss-on-ignition & & & & & $\mathrm{X}$ & & & \\
\hline Actinomycetes bacteria & & & & & & $\mathrm{X}$ & & \\
\hline $\begin{array}{l}\text { Taste-and-odor-causing compounds (2-methylisoborneol, } \\
\text { geosmin) }\end{array}$ & & & $\mathrm{X}$ & & & & $\mathrm{X}$ & \\
\hline Cyanobacterial toxins (total microcystins) & & & & & & & $\mathrm{X}$ & \\
\hline $\begin{array}{l}\text { Phytoplankton (abundance, biovolume, and community } \\
\text { composition to genus) }\end{array}$ & & & & & & & & $\mathrm{X}$ \\
\hline
\end{tabular}


methods in Fishman and Friedman (1989). Nutrients were analyzed by the $\mathrm{COH}$ laboratory according to U.S. Environmental Protection Agency method 365.1 (U.S. Environmental Protection Agency, 1993). Nutrients also were analyzed by the NWQL using methods described in Fishman and Friedman (1989), Fishman (1993), and Patton and Truitt (1992; 2000). Silica and manganese were analyzed by the NWQL (Garbarino and Struzeski, 1998) and by the COH Department of Public Works Water Quality Laboratory (U.S. Environmental Protection Agency, 1994a, b). Fecal indicator bacteria were analyzed at the Texas WSC laboratory. Fecal indicator bacteria, total coliform and E. coli, were analyzed using the defined substrate method (American Public Health Association, American Water Works Association, and Water Environment Federation, 2005, p. 9-72-9-74) and reported as most probable number (MPN) per 100 milliliters. Suspendedsediment concentration was analyzed at the USGS Louisiana WSC Sediment Laboratory in Baton Rouge, La., and Kentucky WSC Sediment Laboratory in Louisville, Ky., using procedures described in Guy (1969). Loss-on-ignition from non-filterable residue also was measured by the USGS Kentucky WSC Sediment Laboratory as described in Fishman and Friedman (1989).

Actinomycetes bacteria were analyzed by the USGS Ohio WSC Microbiology Laboratory in Columbus, Ohio, using standard plate counts (American Public Health Association, American Water Works Association, and Water Environment Federation, 2005, p. 9-109-p. 9-111) and reported in colonies per milliliter.

The taste-and-odor-causing compounds, MIB and geosmin, were analyzed by the $\mathrm{COH}$ laboratory and by the USGS Kansas WSC Organic Geochemistry Research Laboratory (OGRL) in Lawrence, Kans., using methods described in Zimmerman and others (2002).

The cyanobacterial toxin, microcystin, was measured at the OGRL using freeze/thaw extraction (Gjølme and Utkilen, 1994) and 3-amino-9-methoxy-2,6,8-trimethyl-10-phenyldeca4,6-dienoic acid (ADDA) specific enzyme-linked immunosorbent assays (ELISA) (Abraxis, 2007).

Phytoplankton identification (to genus), abundance, and biovolume were done by PhycoTech, Inc., using methods similar to Blomqvist and Herlitz (1998), Olrik and others (1998), and Graham and others (2008). Phytoplankton data summaries include abundance (cell counts) by division, biovolume by division, and a list of observed taxa.

Synoptic samples were analyzed for major ions, trace elements, wastewater indicators, pesticides, VOCs, and carbon (table 3). A suite of major ions and trace elements (November 29, 2007, sample) were analyzed by the NWQL according to methods described in Fishman and Friedman (1989), Fishman (1993), Hoffman and others (1996), Garbarino and Struzeski (1998), and Garbarino and others (2006). Wastewater indicators (November 29, 2007, and September 16, 2008, samples) were analyzed by the NWQL using methods described by Zaugg and others (2006). Pesticides (triazine and phenylurea parents and degradation products) (June 12, 2007, sample)
Table 3. Synoptic water-quality properties and constituents and corresponding analyzing entities for samples collected from Lake Houston near Houston, Texas, 2006-08.

[NWQL, U.S. Geological Survey (USGS) National Water Quality Laboratory, Denver, Colorado; OGRL, USGS Kansas Water Science Center Organic Geochemistry Research Laboratory, Lawrence, Kansas; COH, City of Houston Department of Public Works Water Quality Laboratory, Houston, Texas]

\begin{tabular}{lccc}
\hline \multicolumn{1}{c}{ Constituents } & NWOL & OGRL & COH \\
\hline Major ions and trace elements & $\mathrm{X}$ & & \\
Wastewater indicators & $\mathrm{X}$ & & \\
Pesticides & & $\mathrm{X}$ & \\
Volatile organic compounds & $\mathrm{X}$ & & \\
Carbon & $\mathrm{X}$ & & $\mathrm{X}$ \\
\hline
\end{tabular}

were analyzed by the OGRL using methods described by Lee and others (2002). VOCs (December 12, 2006, sample) were analyzed by the NWQL using methods described by Connor and others (1998). Carbon analyses were done by the NWQL for the July 17, 2007, sample using methods described in Wershaw and others (1987) and for the November 29, 2007, sample using methods described in Brenton and Arnett (1993), American Public Health Association (1995), and U.S. Environmental Protection Agency (1997). Total organic carbon (May 24, 2006, sample) also was analyzed by $\mathrm{COH}$ according to American Public Health Association, American Water Works Association, and Water Environment Federation (2005, p. 9-53-9-55).

\section{Quality Control}

QC samples were collected as described in the "National Field Manual for the Collection of Water-Quality Data" (U.S. Geological Survey, variously dated). QC samples consisted of one equipment blank, zero to two field blanks (varied among constituents), and zero to 74 replicate samples (varied among constituents). QC samples were collected to evaluate possible sources of contamination that might have been introduced during sample collection, processing, transportation, and laboratory analysis, and to quantify the bias and variability of the analytical data. Equipment blanks, field blanks, and associated environmental samples were analyzed using the same methods at the same laboratories. Replicate samples were sent to different laboratories for analysis as a quality-assurance check of the main analytical laboratory as well as an assessment of the variability of the concentration. QC data and results are summarized in table 4. Individual analyzing laboratories conduct their own quality-assurance and QC measures, which are reflected in the resulting data received from each laboratory; those measures are not discussed here.

An equipment blank was collected November 28, 2007, in a controlled environment to determine if the equipment for sample collection and sample processing contributed any 
contamination to the environmental samples (table 5, at end of report). Results of the equipment blank indicate the cleaning procedures and equipment were suitable for sample collection.

Prior to the collection of an environmental sample, field blanks were collected on July 27, 2006, and April 23, 2008. Field blanks were collected and processed at a samplecollection site to evaluate if the collection, processing, or transporting procedures in the field contaminated the environmental sample. Results of field blanks indicate little to no contamination of environmental samples from equipment or processing. For silica, manganese, phosphorus, and suspended sediment, concentrations detected in blanks were substantially lower than in the associated environmental samples and did not create a false positive (constituent incorrectly reported as present in the sample when it is not). Detection of these constituents at low concentrations is common and is attributed to their widespread presence in the environment. Silica was detected in the blank and estimated to be 0.04 milligram per liter $(\mathrm{mg} / \mathrm{L})$, which is the minimum reporting level (MRL) of the $\mathrm{COH}$ Laboratory and the laboratory reporting level (LRL) of the USGS NWQL. The MRL is the lowest measured concentration of a constituent that may be reliably reported using a given analytical method (Childress and others, 1999) and is the most commonly used analytical reporting level of the $\mathrm{COH}$ laboratory. The LRL generally equals twice the annually determined long-term method detection level (LT-MDL) (W.T. Foreman, U.S. Geological Survey, written commun., 2003) and is the most commonly used analytical reporting level of the USGS NWQL. The NWQL approach for determining LT-MDLs and establishing LRLs is described in Childress and others (1999).

Replicate samples were collected during the study to assess data variability associated with different field and analytical methods. The relative percent difference (RPD) between environmental sample results and associated replicate sample results was computed for each environmental samplereplicate pair. RPD is computed as

$$
\mathrm{RPD}=\left|\mathrm{c}_{1}-\mathrm{c}_{2}\right| /\left(\left[\mathrm{c}_{1}+\mathrm{c}_{2}\right] / 2\right) * 100
$$

where

$\mathrm{c}_{1}=$ concentration of environmental sample; and

$c_{2}=$ concentration of replicate sample.

RPD in sample-replicate pairs analyzed for silica concentration ranged from 0.2 to 68.4 percent. The range in RPD for

Table 4. Summary of quality-control data and results for water-quality sampling, Lake Houston near Houston, Texas, $2006-08$.

[E. coli, Escherichia coli; MIB, 2-methylisoborneol; --, not applicable or not computed; RPD, relative percent difference; E, estimated; mg/L, milligrams per liter; $\mu \mathrm{g} / \mathrm{L}$, micrograms per liter; <, less than; cols./100 mL, colonies per 100 milliliters]

\begin{tabular}{|c|c|c|c|c|c|c|c|c|c|c|}
\hline Constituent & Silica & $\begin{array}{l}\text { Manga- } \\
\text { nese }\end{array}$ & $\begin{array}{l}\text { Phos- } \\
\text { phorus }\end{array}$ & $\begin{array}{l}\text { Total } \\
\text { coliform }\end{array}$ & E. coli & $\begin{array}{l}\text { Suspended } \\
\text { sediment }\end{array}$ & $\begin{array}{l}\text { Actino- } \\
\text { mycetes }\end{array}$ & MIB & $\begin{array}{c}\text { Geos- } \\
\text { min }\end{array}$ & $\begin{array}{l}\text { Micro- } \\
\text { cystin }\end{array}$ \\
\hline $\begin{array}{l}\text { Number of environmental } \\
\text { samples }\end{array}$ & 172 & 185 & 176 & 78 & 78 & 189 & 161 & 229 & 229 & 96 \\
\hline Number of replicate samples & 31 & 41 & 74 & 11 & 12 & 5 & 0 & 22 & 22 & 10 \\
\hline $\begin{array}{l}\text { Number of replicate detec- } \\
\text { tions when sample was } \\
\text { nondetection }\end{array}$ & 0 & 0 & 0 & 0 & 0 & 0 & -- & 0 & 1 & 1 \\
\hline $\begin{array}{l}\text { Number of replicate nondetec- } \\
\text { tions when sample was } \\
\text { detection }\end{array}$ & 0 & 0 & 0 & 0 & 0 & 0 & -- & 8 & 14 & 1 \\
\hline Minimum RPD ${ }^{1}$ & .2 & .4 & 0 & 0 & 5.0 & 6.9 & -- & -- & -- & -- \\
\hline Maximum RPD ${ }^{1}$ & 68.4 & 34.3 & 91.3 & 100 & 100 & 40.0 & -- & -- & -- & -- \\
\hline Number of field blanks & 1 & 1 & 2 & 0 & 0 & 1 & 1 & 0 & 0 & 1 \\
\hline $\begin{array}{l}\text { Number of detections in field } \\
\text { blanks (blank concentration/ } \\
\text { environmental concentration) }\end{array}$ & $\begin{array}{l}1(\mathrm{E} .04 / \\
\quad 6.1 \mathrm{mg} / \mathrm{L})\end{array}$ & $\begin{array}{c}1(\mathrm{E} .3 / \\
110 \\
\mu \mathrm{g} / \mathrm{L})\end{array}$ & $\begin{array}{c}1(.009 / \\
.19 \\
\mathrm{mg} / \mathrm{L})\end{array}$ & -- & -- & $\begin{array}{l}1(3 / \\
15 \mathrm{mg} / \mathrm{L})\end{array}$ & 0 & -- & -- & 0 \\
\hline $\begin{array}{l}\text { Number of nondetections in } \\
\text { field blanks (reporting level/ } \\
\text { blank concentration) }\end{array}$ & 0 & 0 & $\begin{array}{c}1(<.008 / \\
<.008 \\
\mathrm{mg} / \mathrm{L})\end{array}$ & -- & -- & 0 & $\begin{array}{l}1(<1 / \\
\quad<1 \text { cols./ } \\
\mathrm{mL})\end{array}$ & -- & -- & $\begin{array}{c}1(<.1 / \\
<.1 \\
\mu g / L)\end{array}$ \\
\hline $\begin{array}{l}\text { Total samples (environmental + } \\
\text { replicates + field blanks) }\end{array}$ & 204 & 227 & 252 & 89 & 90 & 195 & 162 & 251 & 251 & 107 \\
\hline
\end{tabular}

${ }^{1}$ For environmental-replicate pairs in which one or both values of the pair was a censored value $(<)$, the pair was not included in the RPD computation. 
silica replicates is attributed to the difference in methods used by the analyzing laboratories; the $\mathrm{COH}$ laboratory analyzed environmental samples using inductively coupled plasma-mass spectrometry (U.S. Environmental Protection Agency, 1994a, b), whereas the NWQL analyzed replicates using inductively coupled plasma-atomic emission spectrometry (Garbarino and Struzeski, 1998). All sample and replicate data for silica were retained because differences in results due to other factors could not be distinguished from differences due to different analyzing methods.

RPDs for manganese sample-replicate pairs ranged from 0.4 to 34.3 percent. To evaluate the seven RPDs greater than 20 percent out of 42 sample-replicate pairs, manganese concentrations from all samples collected on the same day were compared. Because of the normally high variability of manganese concentrations, especially in lake bottom water, and because different laboratories were used as the primary analyzing laboratory $(\mathrm{COH})$ and the laboratory analyzing the replicates (NWQL) (even though the different laboratories used the same method), a higher RPD is considered acceptable. Therefore concentrations from sample-replicate pairs with greater than 20-percent RPD are considered to be acceptable in these instances.

RPDs for sample-replicate pairs of total (unfiltered) phosphorus ranged from 0 to 91.3 percent. RPDs for low concentrations are expected to be high because small differences at low concentrations result in large RPDs, thus RPDs for low-concentration sample-replicate pairs for total phosphorus are acceptable. The highest detected phosphorus concentration was $0.56 \mathrm{mg} / \mathrm{L}$, whereas most detections ranged from 0.1 to $0.3 \mathrm{mg} / \mathrm{L}$.

RPDs for suspended-sediment sample-replicate pairs ranged from 6.9 to 40.0 percent. Similar to phosphorus, RPDs greater than 20 percent for suspended sediment are associated with low suspended-sediment concentration. The highest RPD for suspended sediment was 40 percent, for which the environmental sample concentration was $2 \mathrm{mg} / \mathrm{L}$ and the replicate sample concentration was $3 \mathrm{mg} / \mathrm{L}$.

For total coliform and E. coli, MPN is a statistical estimate of the actual concentration of fecal indicator bacteria in a water sample within an associated confidence interval. In some cases, RPD for the sample-replicate pair might be high, as much as 100 percent for total coliform in one case. However, for every sample-replicate pair, there was overlap of the confidence intervals for the MPNs for the environmental sample and replicate sample pairs. Overlap of the replicate sample confidence intervals with the environmental sample confidence intervals confirms that the results of the environmental samples and sample pairs are acceptable.

Blank samples were not collected for MIB and geosmin because of the highly unlikely occurrence of environmental contamination of these substances. For the one field blank collected for microcystin, the blank concentration was less than 0.10 microgram per liter $(\mu \mathrm{g} / \mathrm{L})$, the same as the LRL, compared to the environmental sample concentration of less than $0.10 \mu \mathrm{g} / \mathrm{L}$ indicating no environmental contamination.
Replicate samples were collected for MIB, geosmin, and microcystin to confirm potential detections. Overall low concentrations of MIB, geosmin, and microcystin resulted in many nondetections (results less than the method detection level). For all sample-replicate pairs for MIB, geosmin, and microcystin, at least one value of each pair was a nondetection; therefore, RPD could not be computed for these sample-replicate pairs. However, results of sample-replicate pair values were compared. The LRL for geosmin and MIB was $0.005 \mu \mathrm{g} / \mathrm{L}$ at the OGRL. The MRL for geosmin and MIB at the $\mathrm{COH}$ laboratory was usually $0.002 \mu \mathrm{g} / \mathrm{L}$, although on one occasion it was $0.001 \mu \mathrm{g} / \mathrm{L}$. In many pairs, low detected concentrations of one sample are less than the method detection level (a nondetection) of the other sample in the pair. For example, when $0.003 \mu \mathrm{g} / \mathrm{L}$ was reported by one laboratory and less than $0.005 \mu \mathrm{g} / \mathrm{L}$ was reported by the other laboratory, the environmental sample value is close but below the reporting level of the other laboratory; for such cases the sample pair is considered acceptable. In all cases the reported values were at, or near, the MRL or LRL for both laboratories and at such low concentrations the differences between the reported values are not of concern. For microcystin, environmental samples and replicate samples were both analyzed by the OGRL. The LRL for microcystin was $0.10 \mu \mathrm{g} / \mathrm{L}$. In most sample-replicate pairs, microcystin was not detected in either the environmental sample or the replicate sample, and the reported concentration was less than $0.10 \mu \mathrm{g} / \mathrm{L}$ for both. For two pairs, microcystin was not detected in one sample and was detected near the LRL in the other sample. As with geosmin and MIB, the reported concentrations in all pairs were at, or near, the LRL for both laboratories, and at such low concentrations the differences between the reported values are not of concern. All environmental-replicate sample pairs for Geosmin, MIB, and microsystin are considered to be acceptable.

\section{Continuous and Discrete Water-Quality Data}

Continuous and discrete water-quality data collected as part of this study are presented in appendixes 1-1 through $1-10,2-1$ through $2-6$, and 3-1 through 3-5. Appendixes 1-1 through 1-10 contain routinely collected discrete data and corresponding quality-assurance data. Appendixes 2-1 through 2-6 contain discrete data for synoptic samples and corresponding quality-assurance data. Appendixes 3-1 through 3-5 contain summaries of the continuous water-quality data, consisting of minimum, maximum, and daily mean values for each physiochemical property (except $\mathrm{pH}$ ) at each site and depth. In addition to tables containing the minimum, maximum, and daily mean values, appendixes 3-1 through 3-5 also include daily mean values for each physiochemical property (except $\mathrm{pH}$ ) displayed graphically. For $\mathrm{pH}$, only minimum and maximum daily values are included because a statistical mean is not valid for logarithmic values such as $\mathrm{pH}$. Three months 
(June 2008 through September 2008) of continuous data at site A S of RR were removed from the record because of an equipment malfunction.

\section{Summary}

Lake Houston, a reservoir impounded by the City of Houston, Tex., in 1954, is a primary source of drinking water for Houston and surrounding areas. The U.S. Geological Survey (USGS), in cooperation with the City of Houston, developed a continuous water-quality monitoring network to track daily changes in water quality in the southwestern quadrant of Lake Houston beginning in 2006. Continuous water-quality data (the physiochemical properties water temperature, specific conductance, $\mathrm{pH}$, dissolved oxygen concentration, and turbidity) were collected from Lake Houston to characterize the in-lake processes that affect water quality. Continuous data were collected hourly (measured every hour at four different depths in 15-minute intervals) from mobile, multi-depth monitoring stations developed and constructed by the USGS. Multi-depth monitoring stations were installed at five sites in three general locations in the southwestern quadrant of the lake. Two of three original sites were in shallower water than the third original site; those two stations were relocated to deeper parts of the lake partway through the study period so that the maximum water depth at all sites was similar.

Discrete water-quality data (samples) were collected routinely at all sites to characterize the chemical and biological (phytoplankton and bacteria) response to changes in the continuous water-quality properties. Routine samples were collected monthly in April, May, June, and July 2006, prior to installation of the continuous water-quality monitoring stations. Beginning in August 2006, water-quality samples from each monitoring site were collected monthly, with a bi-weekly sampling schedule in the summer. At each site, routine samples were collected at about 1 foot below the water surface, at the midpoint depth of the water column, and at about 1 foot above the bottom of the lake. The physiochemical properties water temperature, specific conductance, $\mathrm{pH}$, dissolved oxygen concentration, turbidity, and transparency were measured in the field when samples were collected. In addition to the routine samples, synoptic samples were collected at all sites one or two times during the study period to determine the presence and levels of selected constituents not analyzed in routine samples. Synoptic samples were collected in the same manner as the routine samples.

Routine samples were measured or analyzed for acid neutralizing capacity; selected major ions and trace elements (calcium, silica, and manganese); nutrients (filtered and total ammonia nitrogen, filtered nitrate plus nitrite nitrogen, total nitrate nitrogen, filtered and total nitrite nitrogen, filtered and total orthophosphate phosphorus, total phosphorus, total nitrogen, total organic carbon); fecal indicator bacteria (total coliform and Escherichia coli); sediment (suspended-sediment concentration and loss-on-ignition); actinomycetes bacteria; taste-and-odor-causing compounds (2-methylisoborneol and geosmin); cyanobacterial toxins (total microcystins); and phytoplankton abundance, biovolume, and community composition (taxonomic identification to genus). Synoptic samples were analyzed for major ions, trace elements, wastewater indicators, pesticides, volatile organic compounds, and carbon.

\section{References Cited}

Abraxis, 2007, Microcystins-DM ELISA (microtiter plate) enzyme-linked immunosorbent assay for the determination of microcystins and nodularins in water samples: Product no. 522011, accessed June 2008 at http://www.abraxiskits. com/moreinfo/PN520011USER1.pdf.

American Public Health Association, 1995, UV-absorbing organic constituents, in Standard methods for the examination of water and wastewater (19th ed.): Washington, D.C., p. 5-60 to 5-62.

American Public Health Association, American Water Works Association, and Water Environment Federation, 2005, Standard methods for the examination of water and wastewater (21st ed.): Washington, D.C.

Blomqvist, P., and Herlitz, E., 1998, Methods for quantitative assessment of phytoplankton in freshwaters, part 2: Stockholm, Naturvårdsverket, Report 4861 [variously paged].

Brenton, R.W., and Arnett, T.L., 1993, Methods of analysis by the U.S. Geological Survey National Water Quality Laboratory-Determination of dissolved organic carbon by uv-promoted persulfate oxidation and infrared spectrometry: U.S. Geological Survey Open-File Report 92-480, 12 p.

Childress, C.J.O., Foreman, W.T., Connor, B.F., and Maloney, T.J., 1999, New reporting procedures based on longterm method detection levels and some considerations for interpretations of water-quality data provided by the U.S. Geological Survey National Water Quality Laboratory: U.S. Geological Survey Open-File Report 99-193, 19 p.

Connor, B.F., Rose, D.L., Noriega, M.C., Murtagh, L.K., and Abney, S.R., 1998, Methods of analysis by the U.S. Geological Survey National Water Quality LaboratoryDetermination of 86 volatile organic compounds in water by gas chromatography/mass spectrometry, including detections less than reporting limits: U.S. Geological Survey Open-File Report 97-829, 78 p.

Fishman, M.J., ed., 1993, Methods of analysis by the U.S. Geological Survey National Water Quality LaboratoryDetermination of inorganic and organic constituents in water and fluvial sediments: U.S. Geological Survey OpenFile Report 93-125, 217 p. 
Fishman, M.J., and Friedman, L.C., 1989, Methods for determination of inorganic substances in water and fluvial sediments: U.S. Geological Survey Techniques of WaterResources Investigations, book 5, chap. A1, 545 p.

Garbarino, J.R., Kanagy, L.K., and Cree, M.E., 2006, Determination of elements in natural-water, biota, sediment, and soil samples using collision/reaction cell inductively coupled plasma-mass spectrometry: U.S. Geological Survey Techniques and Methods, book 5, sec. B, chap. 1, 88 p.

Garbarino, J.R., and Struzeski, T.M., 1998, Methods of analysis by the U.S. Geological Survey National Water Quality Laboratory-Determination of elements in whole-water digests using inductively coupled plasma-optical emission spectrometry and inductively coupled plasma-mass spectrometry: U.S. Geological Survey Open-File Report 98-165, 101 p. [revised July 2003].

Gjølme, N., and Utkilen, H. 1994, A simple and rapid method for extraction of toxic peptides from cyanobacteria, in Codd, G.A., Jefferies, T.M., Keevil, C.W., and Potter, E., eds., Detection methods for cyanobacterial toxins: London, The Royal Society of Chemistry, p. 168-171.

Graham, J.L., Loftin, K.A., Ziegler, A.C., and Meyer, M.T., 2008, Cyanobacteria in lakes and reservoirs - Toxin and taste-and-odor sampling guidelines (version 1.0): U.S. Geological Survey Techniques of Water-Resources Investigations, book 9, chap. A7, section 7.5, online only at http://pubs.water.usgs.gov/twri9A/.

Guy, H.P., 1969, Laboratory theory and methods for sediment analysis: U.S. Geological Survey Techniques of WaterResources Investigations, book 5, chap. C1, 58 p. (Also available at http://pubs.usgs.gov/twri/twri5cl/.)

Hoffman, G.L., Fishman, M.J., and Garbarino, J.R., 1996, Methods of analysis by the U.S. Geological Survey National Water Quality Laboratory-In-bottle acid digestion of whole-water samples: U.S. Geological Survey Open-File Report 96-225, 28 p.

Lee, E.A., Strahan, A.P., and Thurman, E.M., 2002, Methods of analysis by the U.S. Geological Survey Organic Geochemistry Research Group-Determination of triazine and phenylurea herbicides and their degradation products in water using solid-phase extraction and liquid chromatography/mass spectrometry: U.S. Geological Survey Open-File Report 02-436, 19 p.

Lee, R.W., and Rast, Walter, 1997, Light attenuation in a shallow, turbid reservoir, Lake Houston, Texas: U.S. Geological Survey Water-Resources Investigations Report 97-4064, $33 \mathrm{p}$.

Liscum, Fred, and East, J.W., 2000, Estimated effects on water quality of Lake Houston from interbasin transfer of water from the Trinity River, Texas: U.S. Geological Survey Water-Resources Investigations Report 00-4082, 50 p.

Liscum, Fred, Goss, R.L., and Rast, Walter, 1999, Characteristics of water-quality data for Lake Houston, selected tributary inflows to Lake Houston, and the Trinity River near Lake Houston (a potential source of interbasin transfer), August 1983-September 1990: U.S. Geological Survey Water- Resources Investigations Report 99-4129, 56 p.

Oden, T.D., and Graham, J.L., 2008, Watershed influences and in-lake processes - A regional-scale approach to monitoring a water-supply reservoir, Lake Houston near Houston, Texas: U.S. Geological Survey Fact Sheet 2008-3033, 2 p.

Olrik, K., Blomqvist, P., Brettum, P., Cronberg, G., and Eloranta, P., 1998, Methods for quantitative assessment of phytoplankton in freshwaters, part 1: Stockholm, Naturvårdsverket, Report 4860, 86 p.

Patton, C.J., and Truitt, E.P., 1992, Methods of analysis by the U.S. Geological Survey National Water Quality Laboratory-Determination of total phosphorus by a Kjeldahl digestion method and an automated colorimetric finish that includes dialysis: U.S. Geological Survey Open File Report 92-146, 39 p.

Patton, C.J., and Truitt, E.P., 2000, Methods of analysis by the U.S. Geological Survey National Water Quality Laboratory-Determination of ammonium plus organic nitrogen by a Kjeldahl digestion method and an automated photometric finish that includes digest cleanup by gas diffusion: U.S. Geological Survey Open-File Report 00-170, 31 p.

Sneck-Fahrer, D.A., Milburn, M.S., East, J.W., and Oden, J.H., 2005, Water-quality assessment of Lake Houston near Houston, Texas, 2000-2004: U.S. Geological Survey Scientific Investigations Report 05-5241, 64 p.

Texas State Data Center, 2008, Texas population estimates program, 2007-Estimates of the total populations of counties and places in Texas for July 1, 2007 and January 1, 2008: accessed October 13, 2009, at http://txsdc.utsa.edu/ tpepp/txpopest.php.

Texas Water Development Board, 2004, Surface water, lake volumetric surveys: accessed January 15, 2005 , at http://www.twdb.state.tx.us/data/surfacewater/ surfacewater_toc.asp.

U.S. Environmental Protection Agency, 1993, Determination of phosphorus by semi-automated colorimetry, method 365.1, revision 2.0: Cincinnati, Ohio, Environmental Monitoring Systems Laboratory, $17 \mathrm{p}$.

U.S. Environmental Protection Agency, 1994a, Determination of trace elements in waters and wastes by inductively coupled plasma-mass spectrometry, method 200.7, revision 
5.4: Cincinnati, Ohio, Environmental Monitoring Systems Laboratory, 600/R-94-111, 57 p.

U.S. Environmental Protection Agency, 1994b, Determination of trace elements in waters and wastes by inductively coupled plasma-mass spectrometry, method 200.8-1, revision 5.4: Cincinnati, Ohio, Environmental Monitoring Systems Laboratory, 600/R-94-111, $57 \mathrm{p}$.

U.S. Environmental Protection Agency, 1997, Determination of carbon and nitrogen in sediments and particulates of estuarine/coastal waters using elemental analysis, method 440.0, revision 1.4: Cincinnati, Ohio, National Exposure Research Laboratory, Office of Research and Development, $10 \mathrm{p}$.

U.S. Geological Survey, variously dated, National field manual for the collection of water-quality data: U.S. Geological Survey Techniques of Water-Resources Investigations, book 9, chaps. A1-A9, online only at http://pubs.water.usgs.gov/ twri9A.

U.S. Geological Survey, 2009, National Water Information System (NWISWeb)-USGS water data for Texas: online only at http://waterdata.usgs.gov/tx/nwis/nwis.

Wagner, R.J., Boulger, R.W., Jr., Oblinger, C.J., and Smith, B.A., 2006, Guidelines and standard procedures for continuous water-quality monitors-Station operation, record computation, and data reporting: U.S. Geological Survey Techniques and Methods 1-D3, 51 p., 8 attachments. (Also available at http://pubs.usgs.gov/tm/2006/ tm1D3/.)

Wershaw, R.L., Fishman, M.J., Grabbe, R.R., and Lowe, L.E., eds., 1987, Methods for the determination of organic substances in water and fluvial sediments: U.S. Geological Survey Techniques of Water-Resources Investigations, book 5, chap. A3, $80 \mathrm{p}$.

Zaugg, S.D., Smith, S.G., and Schroeder, M.P., 2006, Methods of analysis by the U.S. Geological Survey National Water Quality Laboratory-Determination of wastewater compounds in whole water by continuous liquid-liquid extraction and capillary-column gas chromatography/mass spectrometry: U.S. Geological Survey Techniques and Methods, book 5, chap. B4, 30 p.

Zimmerman, L.R., Ziegler, A.C., and Thurman, E.M., 2002, Method of analysis and quality-assurance practices by U.S. Geological Survey Organic Geochemistry Research Group-Determination of geosmin and methylisoborneol in water using solid-phase microextraction and gas chromatography/mass spectrometry: U.S. Geological Survey OpenFile Report 02-337, 12 p. 


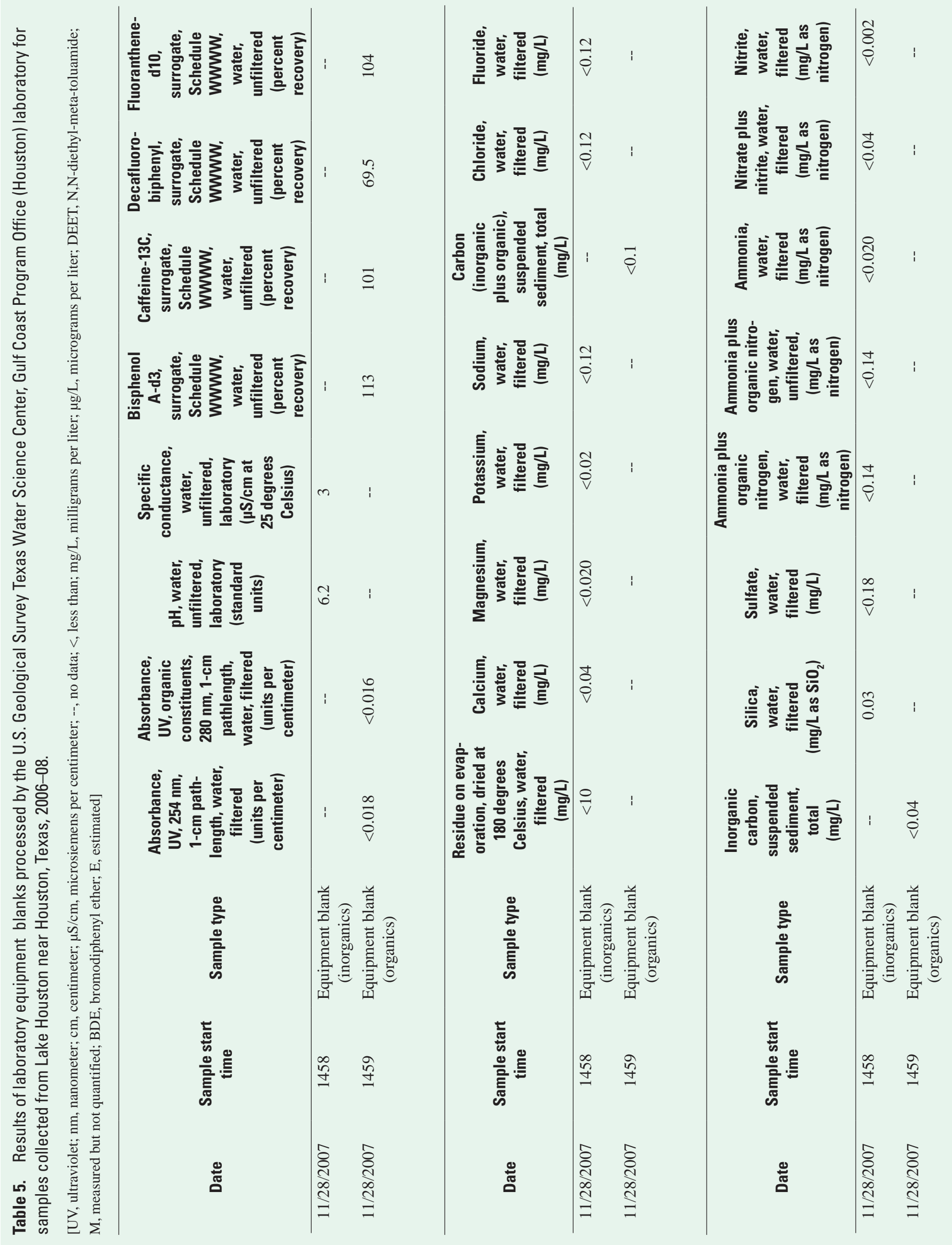




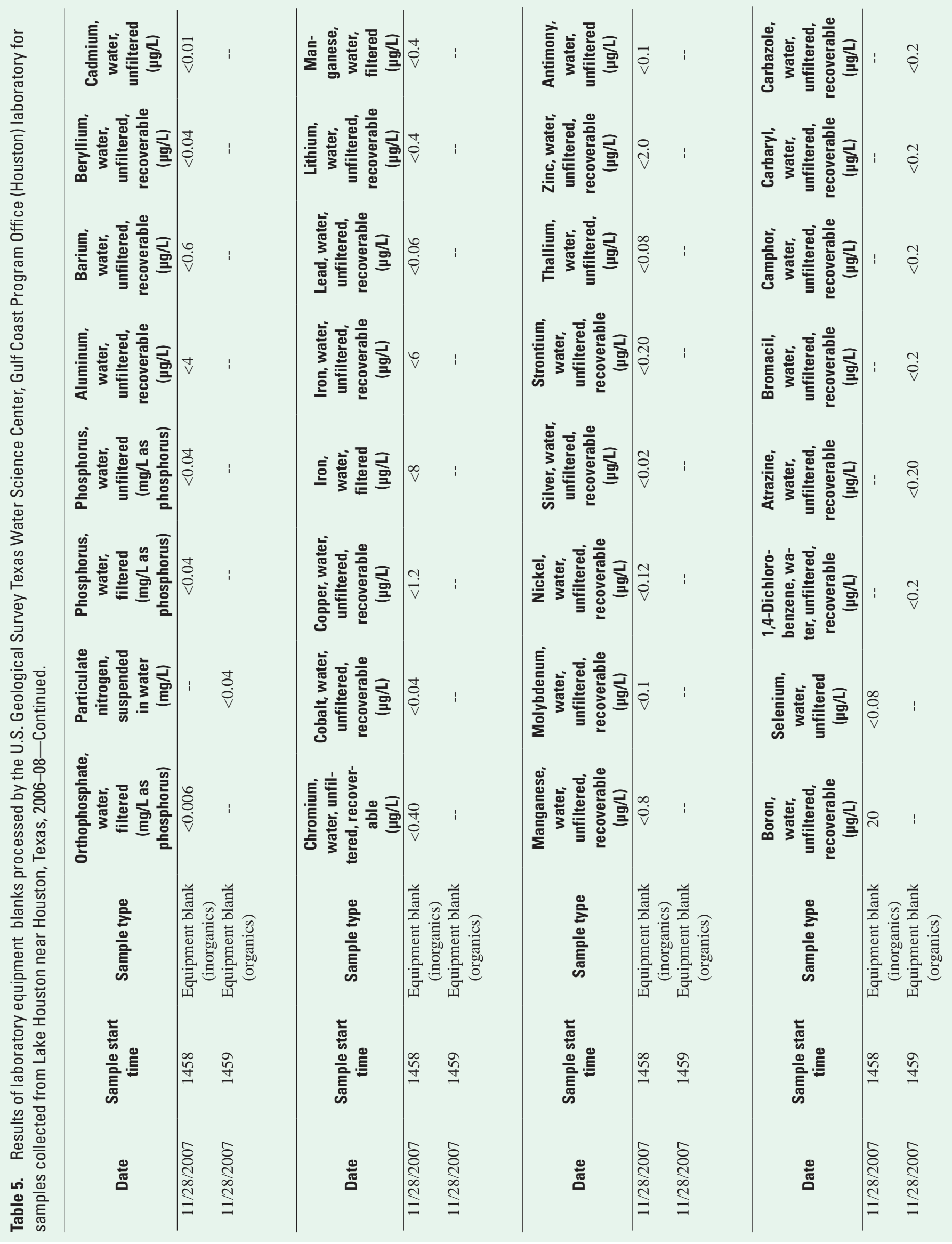




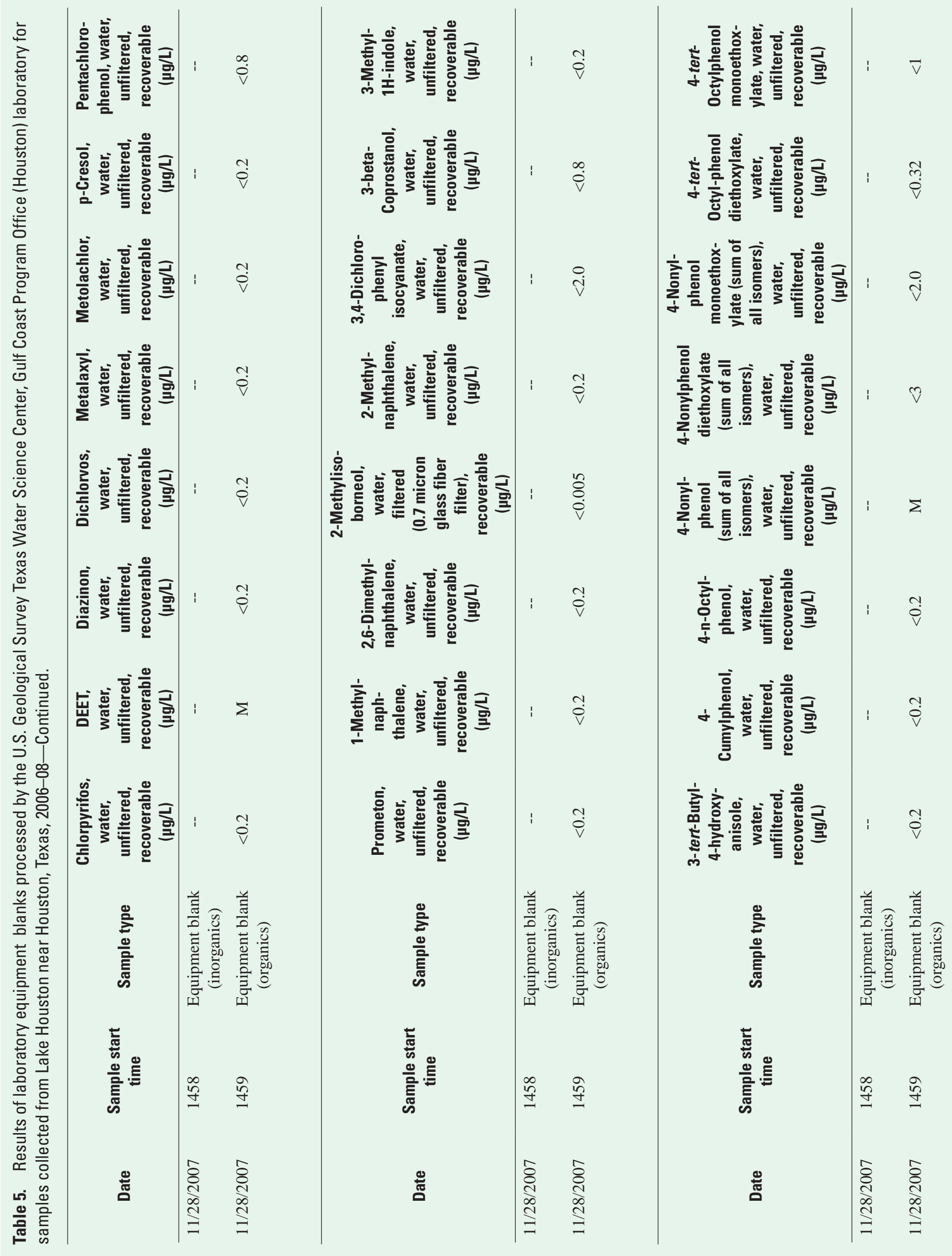




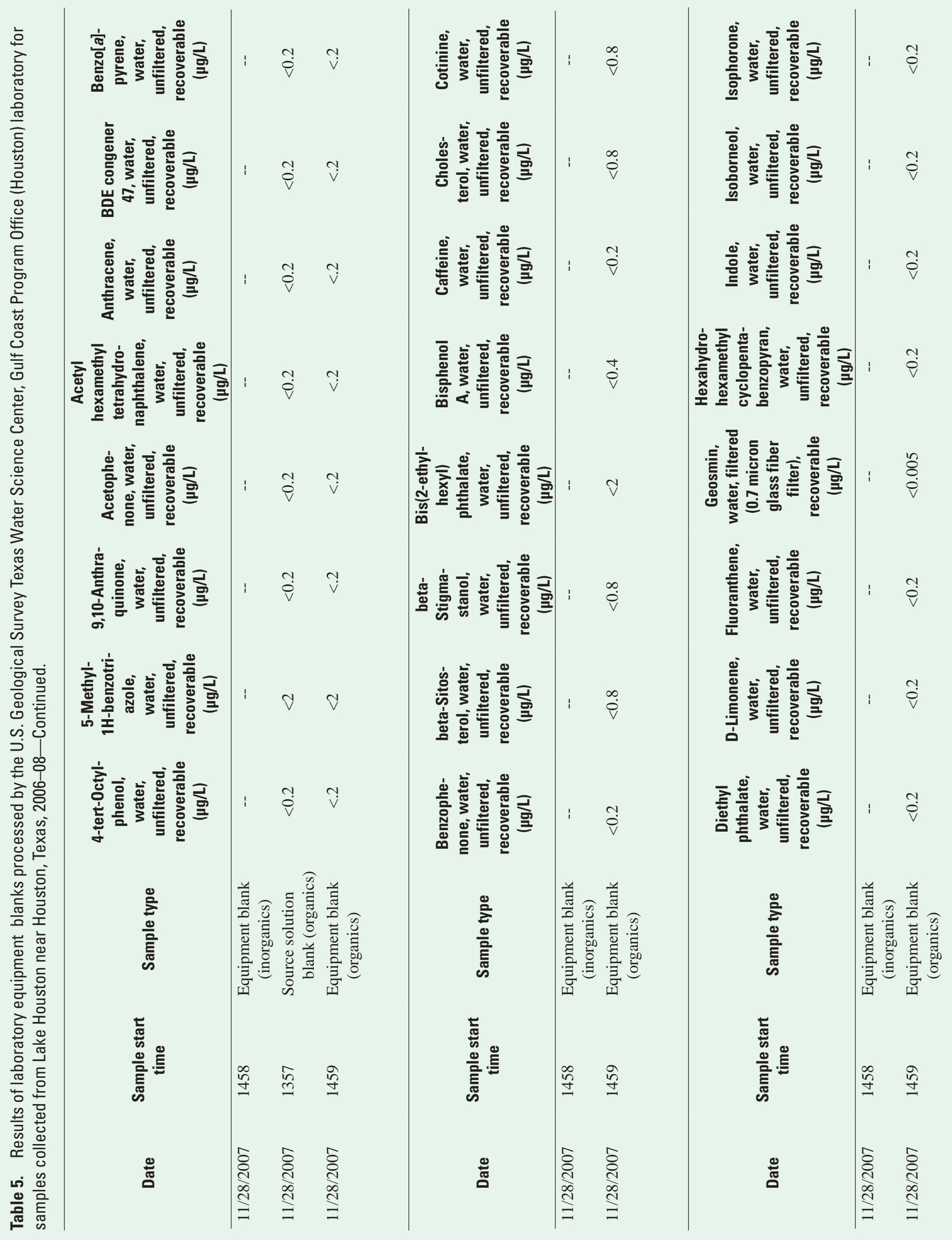




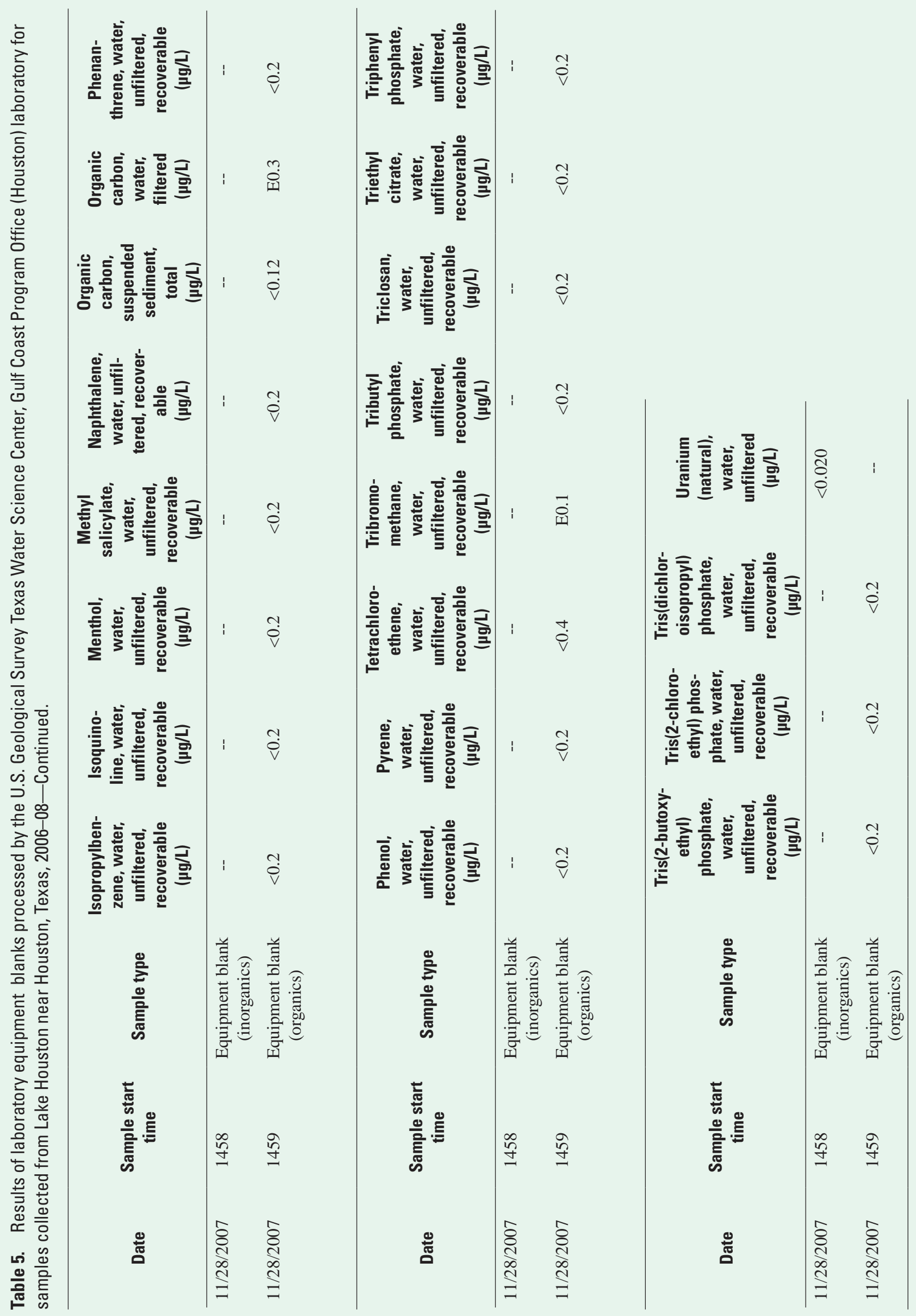


Publishing support provided by Lafayette Publishing Service Center

Information regarding water resources in Texas is available at http://tx.usgs.gov/ 


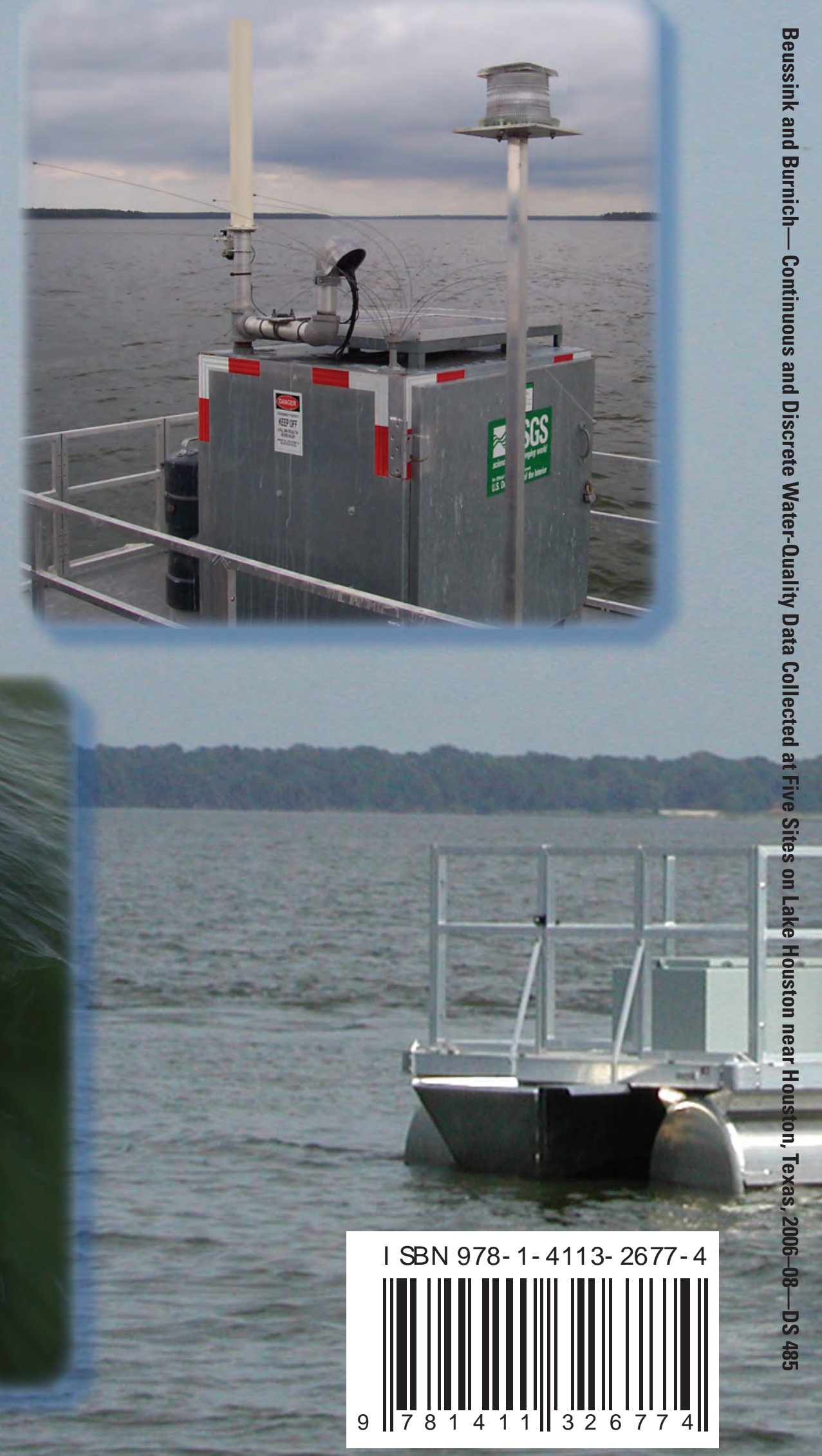

